\title{
An Efficient Synthesis of Methyl Jasmonate and Methyl Dihydrojasmonate
}

\author{
Takeshi Kitahara, Kenji Mori, Masanao Matsui, \\ Minoru Iwamoto, ${ }^{*}$ Yoshikazu TAKAGI* and Yasuhiro WARITA* \\ Department of Agricultural Chemistry, The University of Tokyo, \\ Bunkyo-ku, Tokyo 113, Japan \\ *Kawasaki Research Laboratory, T. Hasegawa Co. Ltd., \\ 355 Kariyado, Nakahara-ku, Kawasaki 211, Japan
}

Received December 24, 1981

\begin{abstract}
A simple and an efficient synthesis of methyl jasmonate (1) and methyl dihydrojasmonate (5) is described. Starting from alkyl acetoacetate or acetonedicarboxylate, $\mathbf{1}$ and $\mathbf{5}$ were obtained in only a few steps via intramolecular Michael addition.
\end{abstract}

Methyl jasmonate (1) is found in Jasminum grandiflorum $\mathrm{L}^{1)}$ and is well known as a key substance for the characteristic odor of jasmine oil. Much attention has been paid to the synthesis of $d l$-methyl jasmonate (1) and related compounds, including jasmone (2), jasmine keto lactone (3), cucurbic $\operatorname{acid}^{2)}(4)$ and methyl dihydrojasmonate (5), because of their usefulness in the perfume industry and as new members of the plant hormones, and various syntheses of 1 have been reported. ${ }^{3)}$ Here we wish to describe a novel and efficient synthesis of methyl jasmonate (1) and methyl dihydrojasmonate (5).

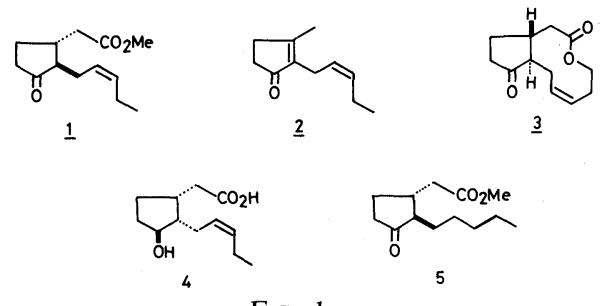

FIG. 1.

Our first plan to employ the Diels-Alder reaction of cyclopentenone (6) with 2-ethoxybutadiene $^{4)}$ (7) turned out to be insufficient, because partial isomerization of the double bond of the desired adduct $(8)$ to the $\Delta^{5,6)}$ isomer (9) caused a low overall yield of $\mathbf{1}$, (less than $5 \%$ ), ${ }^{5}$ so we continued the study to devise a better procedure.

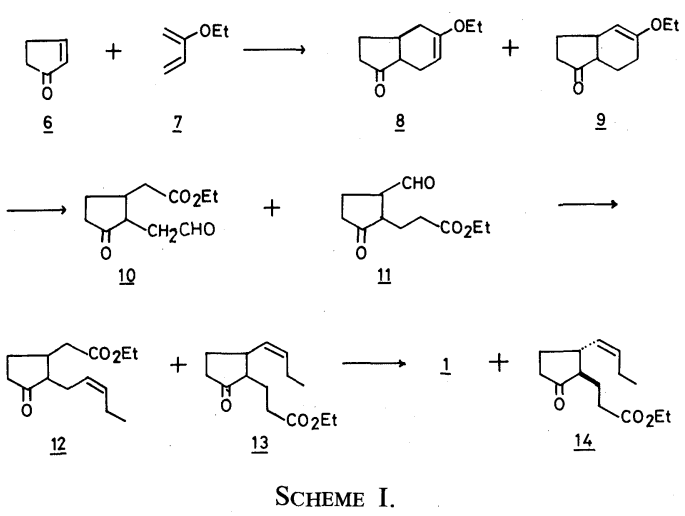

\section{Intramolecular Michael route-1}

In order to improve the yield, an intramolecular Michael-type reaction was examined, and therefore intermediates $A$ and $B$ were selected for cyclization to the substituted cyclopentanone $(C)$. Alkylation of the dianion ${ }^{6)}$ of acetoacetate (16) with methyl $\gamma$-bromocrotonate (15) was tried at first to afford the intermediate $A$. If the alkylation initially takes place, it should give an anion of $A$ (17) which would spontaneously cyclize to give an anion of a cyclopentanone (18) and subsequent alkylation with RX would give the desired product (19) by a one-pot reaction. 


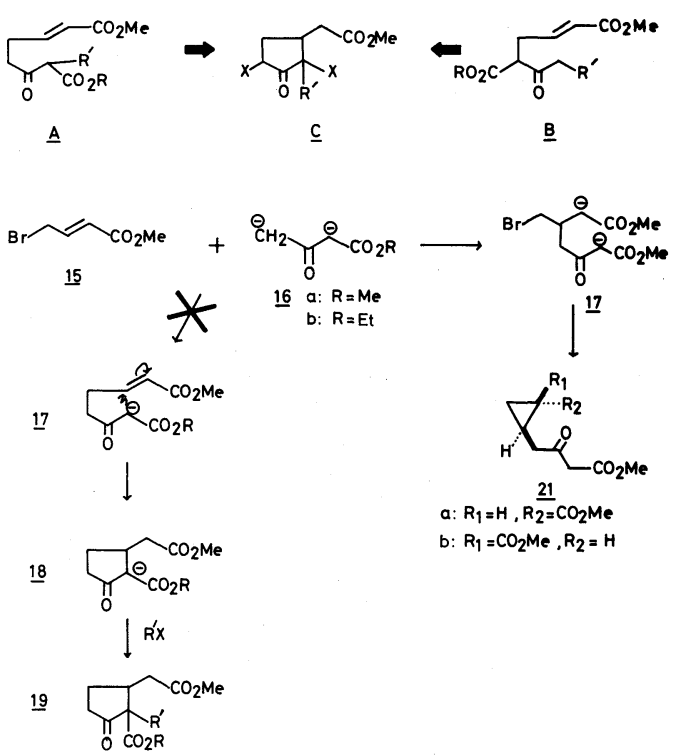

SCHEME II.
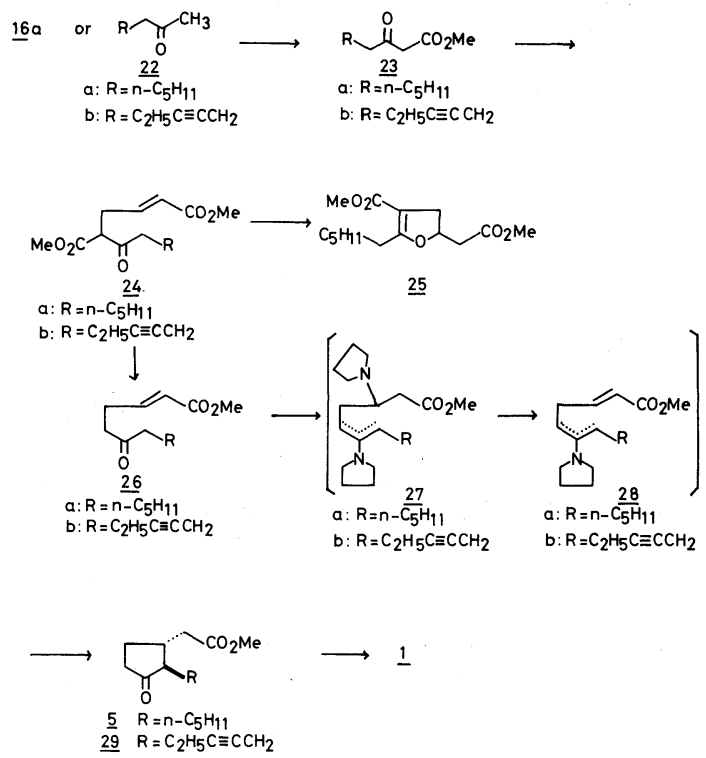

SCHEME III.

TABLE I.

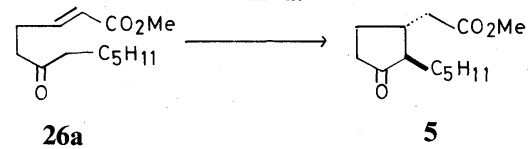

\begin{tabular}{|c|c|c|c|c|c|}
\hline No. & Base & Catalyst & Solvent & $\begin{array}{l}\text { Temperature, } \\
\text { reaction time }\end{array}$ & Yield \\
\hline 1 & $\mathrm{LiH}(0.5$ eq. $)$ & - & THF & Reflux $/ 20 \mathrm{hr}$ & Trace \\
\hline 2 & $\mathrm{NaH}$ (1.0 eq.) & - & DME & Reflux $/ 20 \mathrm{hr}$ & $12 \%$ \\
\hline 3 & $\mathrm{NaH}$ (1.0 eq.) & - & Dioxane & Reflux $/ 20 \mathrm{hr}$ & $15 \%$ \\
\hline 4 & $\mathrm{NaH}$ (1.0 eq.) & - & DME/DMSO & Reflux $/ 20 \mathrm{hr}$ & Trace \\
\hline 5 & $(\mathrm{TMS})_{2} \mathrm{NNa}(0.1$ eq. $)$ & - & Benzene & Reflux $/ 20 \mathrm{hr}$ & Trace \\
\hline 6 & $t \mathrm{BuOK}(0.1$ eq. $)$ & - & $t \mathrm{BuOH}$ & Reflux $/ 20 \mathrm{hr}$ & Trace \\
\hline 7 & $t \mathrm{BuOK}(0.1$ eq. $)$ & - & DME & Reflux $/ 20 \mathrm{hr}$ & Trace \\
\hline 8 & Pyrrolidine (4 eq.) & $\mathrm{TiCl}_{4}(0.2$ eq. $)$ & Benzene & Reflux $/ 20 \mathrm{hr}$ & Trace \\
\hline 9 & Pyrrolidine (4 eq.) & $\mathrm{TiCl}_{4}(0.2$ eq. $)$ & Toluene & Reflux $/ 20 \mathrm{hr}$ & 8 \\
\hline 10 & Pyrrolidine (4 eq.) & $\mathrm{TiCl}_{4}$ (0.2 eq.) & Xylene & Reflux $/ 20 \mathrm{hr}$ & 24 \\
\hline 11 & Pyrrolidine (4 eq.) & TsOH (0.1 eq.) & Xylene & Reflux $/ 20 \mathrm{hr}$ & 15 \\
\hline 12 & Pyrrolidine (4 eq.) & AcOH (0.1 eq.) & Benzene & Reflux $/ 20 \mathrm{hr}$ & 6 \\
\hline 13 & Morpholine (4 eq.) & $\mathrm{TiCl}_{4}$ (0.2 eq.) & Xylene & Reflux $/ 20 \mathrm{hr}$ & 0 \\
\hline
\end{tabular}


Treatment of the dianion $(\mathbf{1 6})^{6)}$ with 15 at room temperature for $15 \mathrm{~min}$, however, afforded a cis, trans mixture (ca. 1 to 3) of cyclopropane derivatives (21) in $76 \%$ yield. These results mean that not alkylation but the Michael addition of $\mathbf{1 6}$ to 15 initially occurred and successive intramolecular alkylation with more reactive anion yielded the undesired product (21). So the intermediate $B$ was alternatively employed for the synthesis. $\beta$-Keto esters $(\mathbf{2 3 a}, \mathbf{b})$ obtainable via alkylation of the dianion (16) or basecatalyzed methoxycarbonylation of the corresponding methylketones (22a, b), were directly alkylated with 15 to give the $B$ type intermediates (24a, b).

Base treatment or $\mathrm{NaCl}-\mathrm{DMSO}$ assisted demethoxycarbonylation ${ }^{7)}$ of 24a did not give the desired cyclization product (5) but afforded a dihydrofuran derivative (25) and therefore 24a, b were submitted to acid-hydrolysis $(6 \mathrm{~N}$ $\mathrm{HCl}-\mathrm{MeOH}=1: 2$, reflux). Only the activated ester group in the molecule was hydrolyzed and subsequently decarboxylated via this procedure to give ketoesters $(\mathbf{2 6 a}, \mathbf{b})$, which were submitted to a cyclization reaction by employing various base catalysts. (See Table I.) As shown in Table I, an inorganic base-catalyzed reaction did not give a good result and finally it was found that using pyrrolidine with $\mathrm{TiCl}_{4}$ afforded the best result. Thus refluxing precursors (26a, b) with excess pyrrolidine and $\mathrm{TiCl}_{4}(0.25$ eq. $)$ in benzene gave enaminopyrrolidine esters $(\mathbf{2 7} \mathbf{a}, \mathbf{b})$ which without purification were heated in xylene for $20 \mathrm{hr}$ to give cyclopentanones $(\mathbf{5}, \mathbf{2 9})$, after hydrolytic workup in $30 \sim 40 \%$ yield based on the recovery of 26a, b. Partial hydrogenation of 29 afforded 1 nearly in quantitative yield. Total yield of $\mathbf{1}$ for the overall 5 steps, however, was not more than $15 \%$ in this procedure, because strenuous conditions were required to effect the cyclization.

\section{Intramolecular Michael route-2}

In order to activate the methylene group adjacent to the carbonyl function in the precursors, we had to use more expensive dialkyl

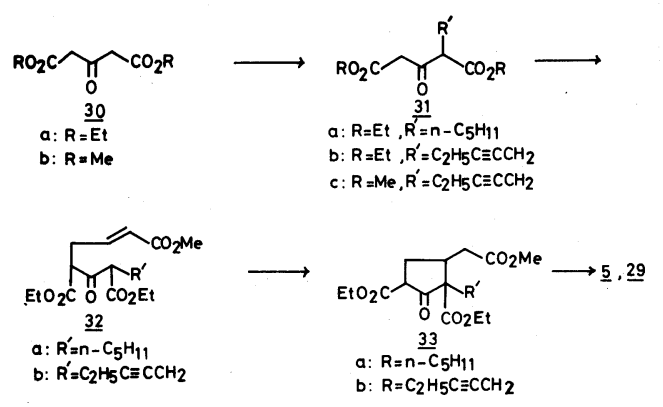

SCHEME IV.

acetonedicarboxylate as a starting material instead of acetoacetic ester.

Recently, Naoshima, Ueda et al. reported an excellent procedure to afford a monoalkylation product of acetonedicarboxylate by employing $\mathrm{Mg}(\mathrm{OEt})_{2}$ as a base. ${ }^{8)} \mathrm{We}$ also studied the modification of this alkylation under various conditions, the results of which are shown in Table II. It is noteworthy that even $\mathrm{LiOH}$ and $\mathrm{K}_{2} \mathrm{CO}_{3}$ were useful bases in the case of 2-pentynyl halide. This modification should be very important, because these are cheaper bases and it did not need to be done under anhydrous conditions, although the yields were slightly lowered (up to $75 \%$ ). Second alkylation was achieved with bromocrotonate (15) under the ordinary procedure $(\mathrm{NaH}$ THF) to give enone-triesters $(32 \mathbf{a}, \mathbf{b})$ in a 80 and $91 \%$ yield respectively, based on the recovery of $31 \mathbf{a}, \mathbf{b}$, which were refluxed with $\mathrm{NaH}$ in benzene for $20 \mathrm{hr}$ to give cyclopentanones (33a, b) in a 73 and $68 \%$ yield. Treatment of 33a, b with $6 \mathrm{~N} \mathrm{HCl}-\mathrm{MeOH}$ $(1: 2)$ afforded selectively hydrolyzed and decarboxylated products $(5,29)$ in a 66 and $70 \%$ yield. 1 was obtained in a $38 \%$ yield for an overall 5 steps. It was unnecessary to isolate the intermediate (32) and thus the alkylation and successive Michael reaction could be done in one pot using excess base. Then, without purification of the crude product (33), decarboxylation was effected to give 5 and 29 in a good overall yield. In this manner, methyl jasmonate (1) was synthesized in $42 \%$ total yield for an overall 4 steps from acetonedicarboxylate (30). Thus a short and efficient synthesis of jasmonoid analogues was estab- 
TABLE II.

\begin{tabular}{|c|c|c|c|c|c|c|}
\hline No. & Substrate & $\mathbf{R}^{\prime}$ & Base & Solvent & $\begin{array}{l}\text { Temperature } \\
\text { reaction time }\end{array}$ & Yield (31) \\
\hline 1 & $30 \mathrm{~b}$ & $n \mathrm{C}_{5} \mathrm{H}_{11}$ & $\mathrm{Mg}(\mathrm{OMe})_{2}$ & $\mathrm{MeOH}$ & $\mathrm{Ref} / 10 \mathrm{hr}$ & $62 \%$ \\
\hline 2 & $30 \mathrm{~b}$ & $n \mathrm{C}_{5} \mathrm{H}_{11}$ & $\mathrm{LiOH}$ & $\mathrm{MeOH}$ & $\mathrm{Ref} / 10 \mathrm{hr}$ & Trace \\
\hline 3 & $30 \mathrm{~b}$ & $n \mathrm{C}_{5} \mathrm{H}_{11}$ & $\mathrm{~K}_{2} \mathrm{CO}_{3}$ & $\mathrm{MeOH}$ & $\mathrm{Ref} / 10 \mathrm{hr}$ & Trace \\
\hline 4 & $30 \mathrm{~b}$ & $n \mathrm{C}_{5} \mathrm{H}_{11}$ & $\mathrm{NaH}$ & THF & $t_{R} / 20 \mathrm{hr}$ & $26 \%$ \\
\hline 5 & 30a & $n \mathrm{C}_{5} \mathrm{H}_{11}$ & $\mathrm{Mg}(\mathrm{OEt})_{2}$ & EtOH & $\mathrm{Ref} / 10 \mathrm{hr}$ & $96 \%$ \\
\hline 6 & 30a & $n \mathrm{C}_{5} \mathrm{H}_{11}$ & $\mathrm{LiOH}$ & EtOH & $\mathrm{Ref} / 10 \mathrm{hr}$ & Trace \\
\hline 7 & 30b & $\mathrm{C}_{2} \mathrm{H}_{5} \mathrm{C} \equiv \mathrm{CCH}_{2}$ & $\mathrm{Mg}(\mathrm{OMe})_{2}$ & $\mathrm{MeOH}$ & $\operatorname{Ref} / 10 \mathrm{hr}$ & $68 \%$ \\
\hline 8 & $30 \mathbf{b}$ & $\mathrm{C}_{2} \mathrm{H}_{5} \mathrm{C} \equiv \mathrm{CCH}_{2}$ & $\mathrm{LiOH}$ & $\mathrm{MeOH}$ & $\mathrm{Ref} / 10 \mathrm{hr}$ & $72 \%$ \\
\hline 9 & $30 \mathrm{~b}$ & $\mathrm{C}_{2} \mathrm{H}_{5} \mathrm{C} \equiv \mathrm{CCH}_{2}$ & $\mathrm{~K}_{2} \mathrm{CO}_{3}$ & $\mathrm{MeOH}$ & $\operatorname{Ref} / 10 \mathrm{hr}$ & $53 \%$ \\
\hline 10 & $30 \mathrm{~b}$ & $\mathrm{C}_{2} \mathrm{H}_{5} \mathrm{C} \equiv \mathrm{CCH}_{2}$ & $\mathrm{NaH}$ & THF & $t_{R} / 10 \mathrm{hr}$ & $29 \%$ \\
\hline 11 & 30a & $\mathrm{C}_{1} \mathrm{H}_{5} \mathrm{C} \equiv \mathrm{CCH}_{2}$ & $\mathrm{Mg}(\mathrm{OEt})_{2}$ & $\mathrm{EtOH}$ & $\mathrm{Ref} / 10 \mathrm{hr}$ & $92 \%$ \\
\hline 12 & 30a & $\mathrm{C}_{2} \mathrm{H}_{5} \mathrm{C} \equiv \mathrm{CCH}_{2}$ & $\mathrm{LiOH}$ & EtOH & $\mathrm{Ref} / 10 \mathrm{hr}$ & $75 \%$ \\
\hline
\end{tabular}

lished. Synthesis of jasmine keto lactone (3) and related jasmonoids is now in progress in our laboratory and will be published in due course. $^{9)}$

\section{EXPERIMENTAL}

All bps were uncorrected. IR were determined on a Shimadzu IRA-400 and a JASCO IRA-2 spectrometer. NMR spectra were recorded at $60 \mathrm{MHz}$ with TMS as an internal standard on a Varian EM-360 and a Hitachi R24A spectrometer. MS spectra were obtained on a Hitachi RMU-5M GC-MS spectrometer.

Dimethyl 5-heptanoyl-2(E)-hexene-1,6-dioate (24a).

a) From methyl acetoacetate (16a). To the solution of the dianion of 16a (11.6g) in dry THF, prepared in the same manner as reported, ${ }^{6}$ was added dropwise a solution of $n$-amyl bromide $(15.0 \mathrm{~g})$ in dry THF over $10 \mathrm{~min}$ at $0^{\circ} \mathrm{C}$ under $\mathrm{N}_{2}$, the mixture being stirred for further $1 \mathrm{hr}$ at room temperature. To this was added dropwise a solution of methyl $\gamma$-bromocrotonate $(15,17.9 \mathrm{~g})$ in dry THF $(10 \mathrm{ml})$ over $10 \mathrm{~min}$ at $0^{\circ} \mathrm{C}$. After stirring for $20 \mathrm{hr}$ at room temperature, the reaction mixture was poured into $\mathrm{NH}_{4} \mathrm{Cl}$ aq: and extracted with ether. The extract was washed with brine, dried over $\mathrm{MgSO}_{4}$ and concentrated. The residue was distilled to give $24 \mathrm{a}\left(15.3 \mathrm{~g}, 54^{\circ} \mathrm{o}\right)$ : bp $145 \sim 148^{\circ} \mathrm{C} / 0.05$
mmHg. IR $v_{\max }^{\text {film }} \mathrm{cm}^{-1}: 1735,1715,1650,980$. NMR $\left(\mathrm{CDCl}_{3}\right) \delta: 0.88(3 \mathrm{H}, \mathrm{t}, J=7 \mathrm{~Hz}), 1.0 \sim 1.9(8 \mathrm{H}), 2.2 \sim 2.9$ $(4 \mathrm{H}), 3.63(1 \mathrm{H}, \mathrm{t}, J=7 \mathrm{~Hz}), 3.71(3 \mathrm{H}, \mathrm{s}), 3.74(3 \mathrm{H}, \mathrm{s}), 5.89$ $(1 \mathrm{H}, \mathrm{d}-\mathrm{t}, J=16,1 \mathrm{~Hz}), 6.90(1 \mathrm{H}, \mathrm{d}-\mathrm{t}, J=16,7 \mathrm{~Hz})$.

b) From 2-octanone (22a). To a stirred suspension of $\mathrm{NaH}(6.0 \mathrm{~g}$ of $60 \%$ mineral oil dispersion) in dry THF $(150 \mathrm{ml})$ was added dropwise a mixture of 2-octanone $(15.5 \mathrm{~g})$ and dimethyl carbonate $(13.5 \mathrm{~g})$ in dry THF $(20 \mathrm{ml})$ over $10 \mathrm{~min}$ at room temperature, the mixture being stirred for $20 \mathrm{hr}$. To this was added dropwise a solution of methyl $\gamma$-bromocrotonate $(21.5 \mathrm{~g})$ in dry THF $(20 \mathrm{ml})$ over $10 \mathrm{~min}$ at room temperature. After stirring for a further $20 \mathrm{hr}$ at room temperature, the reaction mixture was quenched with $\mathrm{NH}_{4} \mathrm{Cl}$ aq. and worked up in the same manner as described above. Distillation afforded the recovered 22a $(5.6 \mathrm{~g})$ and $24 \mathrm{a}(18.9 \mathrm{~g}, 86 \%$ based on the recovery of 22a).

Dimethyl 5-(4-heptynoyl)-2(E)-hexene-1,6-dioate (24b). The dianion prepared in the same manner from methyl acetoacetate $(11.6 \mathrm{~g})$ was treated with 2-pentynyl bromide $(16.0 \mathrm{~g})$ and subsequently with methyl $\gamma$-bromocrotonate (17.9 g). After the same work-up, the residue was distilled to give $24 \mathrm{~b}(17.3 \mathrm{~g}, 62 \%)$ : bp $164 \sim 167^{\circ} \mathrm{C} / 0.08$ mmHg. IR $v_{\max }^{\text {film }} \mathrm{cm}^{-1}: 1735,1715,1650,975$. NMR $\left(\mathrm{CDCl}_{3}\right) \delta: 1.10(3 \mathrm{H}, \mathrm{t}, J=7 \mathrm{~Hz}), 1.8 \sim 3.0(8 \mathrm{H}), 3.75(3 \mathrm{H}$, s), $3.77(1 \mathrm{H}, \mathrm{t}, J=7 \mathrm{~Hz}), 3.79(3 \mathrm{H}, \mathrm{s}), 5.91(1 \mathrm{H}, \mathrm{d}-\mathrm{t}, J=16$, $1 \mathrm{~Hz}), 6.93(1 \mathrm{H}, \mathrm{d}-\mathrm{t}, J=16,7 \mathrm{~Hz})$. 
Methyl 6-oxo-2(E)-dodecenoate (26a).

a) via Acidic cleavage. A mixture of $24 \mathrm{a}(6.1 \mathrm{~g})$ and $6 \mathrm{~N}$ $\mathrm{HCl}$ aq. $(20 \mathrm{ml})$ in $\mathrm{MeOH}(40 \mathrm{ml})$ was refluxed for $20 \mathrm{hr}$. The reaction mxiture was cooled, diluted with water and extracted with ether. The extract was washed with $\mathrm{NaHCO}_{3}$ aq. and brine, dried over $\mathrm{MgSO}_{4}$ and concentrated. The residue was distilled to give $26 \mathrm{a}(4.0 \mathrm{~g}$, $84^{\circ} \%$ ): bp $108 \sim 110^{\circ} \mathrm{C} / 0.08 \mathrm{mmHg}$. IR $v_{\max }^{\text {film }} \mathrm{cm}^{-1}: 1720$, $1710,1655,975$. NMR $\left(\mathrm{CDCl}_{3}\right) \delta: 0.90(3 \mathrm{H}, \mathrm{t}, J=7 \mathrm{~Hz})$, $1.0 \sim 1.9(8 \mathrm{H}), 2.2 \sim 2.9(6 \mathrm{H}), 3.74(3 \mathrm{H}, \mathrm{s}), 5.86(1 \mathrm{H}, \mathrm{d}-\mathrm{t}$, $J=16,1 \mathrm{~Hz}), 7.02(1 \mathrm{H}, \mathrm{d}-\mathrm{t}, J=16,7 \mathrm{~Hz}) . \mathrm{MS} m / z 226$ (9\%), 156 (17), 124 (18), 113 (100), 109 (17), 97 (17), 96 (32), 85 (29), 81 (27), 71 (30), 57 (20), 55 (25), 43 (48), 41 (38).

b) via DMSO-NaCl Procedure. A mixture of $24 \mathrm{a}(1.0 \mathrm{~g})$, water $(0.2 \mathrm{~g})$ and $\mathrm{NaCl}(0.3 \mathrm{~g})$ in DMSO $(3.0 \mathrm{ml})$ was stirred at $160^{\circ} \mathrm{C}$ for $6 \mathrm{hr}$. The reaction mixture was cooled, diluted with water and extracted with ether. The extract was washed with brine, dried over $\mathrm{MgSO}_{4}$ and concentrated. The residue on $\mathrm{SiO}_{2}$ chromatography $(100 \mathrm{~g})$ eluted with $n$-hexane-EtOAc $(85: 15)$ gave $26 a(320 \mathrm{mg}$, $40 \%$ and 2-hexyl-3-methoxycarbonyl-5-methoxycarbonylmethyl-4,5-dihydrofuran (25) $(82 \mathrm{mg}, 8 \%)$.

25: IR $v_{\max }^{\mathrm{film}} \mathrm{cm}^{-1}: 1730,1690,1640,985 . \mathrm{NMR}\left(\mathrm{CDCl}_{3}\right)$ $\delta: 0.89(3 \mathrm{H}, \mathrm{t}, J=7 \mathrm{~Hz}), 1.05 \sim 1.75(8 \mathrm{H}), 2.30 \sim 3.30(6 \mathrm{H}$, $\mathrm{m}), 3.70(3 \mathrm{H}, \mathrm{s}), 3.72(3 \mathrm{H}, \mathrm{s}), 4.80 \sim 5.20(1 \mathrm{H}, \mathrm{m})$. MS $m / z$ $284(16 \%), 253(21), 211$ (100), 195 (30), 183 (17), $179(20)$, 141 (25), 140 (30), 139 (21), 113 (25), 109 (23), 81 (30), 74 (32), 59 (40), 55 (53), 43 (70), 41 (51).

Methyl 6-oxo-2 (E)-dodecen-9-ynoate (26a). In the same manner, 24b $(6.0 \mathrm{~g})$ was treated with $6 \mathrm{~N} \mathrm{HCl}$ aq. $(20 \mathrm{ml})$ in $\mathrm{MeOH}(40 \mathrm{ml})$ to give $26 \mathrm{~b}(3.7 \mathrm{~g}, 78 \%)$ : bp $106 \sim 108^{\circ} \mathrm{C} /$ $0.05 \mathrm{mmHg}$. IR $v_{\max }^{\text {film }} \mathrm{cm}^{-1}: 1720,1710,1655,975$. NMR $\left(\mathrm{CDCl}_{3}\right) \delta: 1.08(3 \mathrm{H}, \mathrm{t}, J=7 \mathrm{~Hz}), 1.8 \sim 2.9(10 \mathrm{H}), 3.72(3 \mathrm{H}$, s), $5.84(1 \mathrm{H}, \mathrm{d}-\mathrm{t}, J=16,1 \mathrm{~Hz}), 6.98(1 \mathrm{H}, \mathrm{d}-\mathrm{t}, J=16,7 \mathrm{~Hz})$. MS $m / z 222$ (4\%), 123 (69), 122 (38), $113(35), 109$ (58), 81 (100), 79 (42), 71 (46), 53 (54), 41 (69).

\section{Methyl dihydrojasmonate (5) from 26a.}

a) A solution of $26 \mathrm{a}(2.0 \mathrm{~g})$ in dry benzene $(200 \mathrm{ml})$ containing pyrrolidine $(2.5 \mathrm{~g})$ and $\mathrm{TiCl}_{4}(0.4 \mathrm{~g})$ was refluxed for $6 \mathrm{hr}$ with continuous azeotropic removal of the water. The reaction mixture was concentrated in vacuo and the residue was diluted with dry xylene $(200 \mathrm{ml})$ and the mixture refluxed for $20 \mathrm{hr}$. To the cooled reaction mixture was added a solution of NaOAc $(5.0 \mathrm{~g})$ in $50 \% \mathrm{AcOH}$ aq. $(20 \mathrm{ml})$. After refluxing for $1 \mathrm{hr}$, the reaction mixture was cooled, washed with water, $\mathrm{NaHCO}_{3}$ aq. and brine, dried over $\mathrm{MgSO}_{4}$ and concentrated. The residue on $\mathrm{SiO}_{2}$ chromatography $(80 \mathrm{~g})$ eluted with $n$-hexane-EtOAc $(9: 1)$ gave the recovered $26 \mathrm{a}(480 \mathrm{mg})$ and $5(605 \mathrm{mg}, 40 \%$ based on the recovery of 26a: IR $v_{\max }^{\text {film }} \mathrm{cm}^{-1}: 1735$. NMR $\left(\mathrm{CDCl}_{3}\right) \delta: 0.90(3 \mathrm{H}, \mathrm{t}, J=7 \mathrm{~Hz}), 1.1 \sim 2.8(16 \mathrm{H}), 3.70(3 \mathrm{H}$, s). MS $m / z$ : $226(2.5 \%), 156(16), 153(15), 83$ (100), 82 (25), 55 (31), 41 (40). These data of synthetic 5 were identical to those of the authentic sample. b) A mixture of $26 \mathrm{a}(200 \mathrm{mg}), \mathrm{TiCl}_{4}(40 \mathrm{mg})$ and pyrrolidine $(250 \mathrm{mg})$ in dry toluene $(20 \mathrm{ml})$ was refluxed for $20 \mathrm{hr}$ with continuous azeotropic removal of the water. To this was added $2 \mathrm{~N} \mathrm{HCl}$ aq. $(20 \mathrm{ml})$ and the mixture refluxed for $30 \mathrm{~min}$. The reaction mixture was cooled and the organic layer was separated, washed with water, $\mathrm{NaHCO}_{3}$ aq. and brine, dried over $\mathrm{MgSO}_{4}$ and concentrated. The residue on $\mathrm{SiO}_{2}$ chromatography $(10 \mathrm{~g})$ eluted with $n$-hexane-EtOAc $(9: 1)$ gave the recovered 26a (42 $\mathrm{mg}, 21 \%$ ) and $5(16 \mathrm{mg}, 8 \%$ ). The mother liquor was neutralized with $\mathrm{NaHCO}_{3}$ aq. and extracted with ether. The extract was washed with brine, dried over $\mathrm{MgSO}_{4}$ and concentrated in vacuo to give methyl 6-oxo-3-(1pyrrolidine) dodecanoate $(69 \mathrm{mg}, 26 \%):$ IR $v_{\max }^{\text {film }} \mathrm{cm}^{-1}$ : 1730, 1710. NMR $\left(\mathrm{CDCl}_{3}\right) \delta: 0.90(3 \mathrm{H}, \mathrm{t}, J=7 \mathrm{~Hz})$, $1.05 \sim 2.10(14 \mathrm{H}), 2.10 \sim 3.00(10 \mathrm{H}, \mathrm{m}), 3.00 \sim 3.20(1 \mathrm{H}$, $\mathrm{m}), 3.65(3 \mathrm{H}, \mathrm{s})$.

c) A mixture of $26 \mathrm{a}(200 \mathrm{mg})$ and $\mathrm{NaH}(40 \mathrm{mg}$ of $60 \%$ mineral oil dispersion) in dry dioxane $(10 \mathrm{ml})$ was refluxed for $20 \mathrm{hr}$ under $\mathrm{N}_{2}$. The reaction mixture was cooled, poured into $\mathrm{NH}_{4} \mathrm{Cl}$ aq. and extracted with ether. The extract was washed with brine, dried over $\mathrm{MgSO}_{4}$ and concentrated. The residue on $\mathrm{SiO}_{2}$ chromatography $(10 \mathrm{~g})$ eluted with $n$-hexane-EtOAc $(9: 1)$ gave the recovered $26 a$ (44 mg, 22\%) and 5 (30 mg, 15\%).

Methyl dehydrojasmonate (29) from 26b. 26b (2.0 g) was treated in the same manner as described above ( 5 from 26a, column a) to give the recovered $26 \mathrm{~b}(590 \mathrm{mg})$ and 29 ( $440 \mathrm{mg}, 31 \%$ based on the recovery of $26 \mathrm{~b}$ ): IR $v_{\max }^{\text {film }} \mathrm{cm}^{-1}$ : 1735. NMR $\left(\mathrm{CDCl}_{3}\right) \delta: 1.09(3 \mathrm{H}, \mathrm{t}, J=7 \mathrm{~Hz}), 1.5 \sim 2.9$ (12H), $3.72(3 \mathrm{H}, \mathrm{s})$. MS $m / z: 222(1 \%), 193$ (27), 133 (16), 122 (100), 107 (52), $91(30), 79(30), 41$ (31). The physical data of synthetic 29 were identical to those reported. ${ }^{3 d, h}$

\section{Methyl jasmonate (1).}

a) A mixture of $29(100 \mathrm{mg})$ and Lindlar catalyst $(200 \mathrm{mg})$ in $\mathrm{MeOH}(2 \mathrm{ml})$ was stirred at room temperature under 1 atm of $\mathrm{H}_{2}$. After the $\mathrm{H}_{2}$-uptake ceased in $2 \mathrm{hr}$, the mixture was filtered and the filtrate was concentrated. The residue on $\mathrm{SiO}_{2}$ chromatography $(12 \mathrm{~g})$ eluted with $n$ hexane-EtOAc (95:5) gave $1(93 \mathrm{mg}, 93 \%)$ : IR $v_{\max }^{\text {film }} \mathrm{cm}^{-1}$ : 1735. NMR $\left(\mathrm{CDCl}_{3}\right) \delta: 0.96(3 \mathrm{H}, \mathrm{t}, J=7 \mathrm{~Hz}), 1.52 \sim 2.8$ (12H), $3.70(3 \mathrm{H}, \mathrm{s}), 5.38(2 \mathrm{H}, \mathrm{m})$. MS m/z $224(20 \%), 156$ (18), 151 (40), 83 (100), 41 (58). These data for synthetic 1 were identical with those of the authentic sample.

b) A mixture of $26 \mathrm{~b}(7.0 \mathrm{~g})$, quinoline $(0.7 \mathrm{~g})$ and Lindlar catalyst $(0.7 \mathrm{~g})$ in $\mathrm{MeOH}(100 \mathrm{ml})$ was stirred at room temperature under $5 \mathrm{~kg} / \mathrm{cm}^{2}$ of $\mathrm{H}_{2}$ in an autoclave. Hydrogen-uptake ceased in about $1 \mathrm{hr}$ and the mixture was filtered, concentrated and diluted with ether. The ethereal solution was washed with dil $\mathrm{HCl}$ aq., $\mathrm{NaHCO}_{3}$ aq. and brine, dried over $\mathrm{MgSO}_{4}$ and concentrated. The residue was distilled to give $1(6.7 \mathrm{~g}, 95 \%)$. bp $110 \sim 113^{\circ} \mathrm{C} /$ $1 \mathrm{mmHg}$.

cis- and trans-Methyl 4-(2-methoxycarbonyl-1-cyclo- 
propyl)-3-oxobutanoate (21a, b). To a solution of the dianion of methyl acetoacetate $(1.5 \mathrm{~g})$ in THF, prepared as reported, ${ }^{6)}$ was added dropwise a solution of methyl $\gamma$ bromocrotonate $(2.3 \mathrm{~g})$ in dry THF $(20 \mathrm{ml})$ over $10 \mathrm{~min}$ at $0^{\circ} \mathrm{C}$ under $\mathrm{N}_{2}$ and the mixture was stirred for further $5 \mathrm{~min}$ at $0^{\circ} \mathrm{C}$. The reaction mixture was poured into $\mathrm{NH}_{4} \mathrm{Cl}$ aq. and extracted with ether. The extract was washed with brine, dried over $\mathrm{MgSO}_{4}$ and concentrated. The residue on $\mathrm{SiO}_{2}$ chromatography $(100 \mathrm{~g})$ eluted with $n$-hexaneEtOAc $(3: 1)$ gave cis-isomer $(\mathbf{2 1 b}, 0.52 \mathrm{~g}, 19 \%)$ and transisomer $(21 \mathrm{a}, 1.58 \mathrm{~g}, 57 \%)$.

21b: IR $v_{\max }^{\text {film }} \mathrm{cm}^{-1}: 3010,1740,1720$. NMR $\left(\mathrm{CDCl}_{3}\right) \delta$ : $0.80 \sim 2.00(4 \mathrm{H}, \mathrm{m}), 2.92(2 \mathrm{H}, \mathrm{d}, J=7 \mathrm{~Hz}), 3.47(2 \mathrm{H}, \mathrm{s})$, $3.70(3 \mathrm{H}, \mathrm{s}), 3.75(3 \mathrm{H}, \mathrm{s})$.

21a: IR $v_{\max }^{\text {film }} \mathrm{cm}^{-1}: 3020,1745,1720$. NMR $\left(\mathrm{CDCl}_{3}\right) \delta$ : $0.65 \sim 1.80(4 \mathrm{H}, \mathrm{m}), 2.60(2 \mathrm{H}, \mathrm{d}, J=7 \mathrm{~Hz}), 3.49(2 \mathrm{H}, \mathrm{s})$, $3.70(3 \mathrm{H}, \mathrm{s}), 3.75(3 \mathrm{H}, \mathrm{s})$.

Dimethyl 2-(2-pentynyl)-3-oxoglutarate (31c). A mixture of dimethyl 3-oxoglutarate $(3.8 \mathrm{~g})$, 2-pentynyl bromide $(3.5 \mathrm{~g})$ and $\mathrm{LiOH}(0.8 \mathrm{~g})$ in $\mathrm{MeOH}(50 \mathrm{ml})$ was refluxed for $20 \mathrm{hr}$ under $\mathrm{N}_{2}$. The mixture was cooled, poured into $\mathrm{NH}_{4} \mathrm{Cl}$ aq. and extracted with ether. The extract was washed with brine, dried over $\mathrm{MgSO}_{4}$ and concentrated. The residue was distilled to give 31c (3.8 g, $72 \%$ ): bp $127 \sim 132^{\circ} \mathrm{C} / 1 \mathrm{mmHg}$. IR $v_{\max }^{\text {film }} \mathrm{cm}^{-1}: 1740,1720$. NMR $\left(\mathrm{CDCl}_{3}\right) \delta: 1.05(3 \mathrm{H}, \mathrm{t}, J=7 \mathrm{~Hz}), 2.11(2 \mathrm{H}, \mathrm{t}-\mathrm{q}$, $J=2,7 \mathrm{~Hz}), 2.68(2 \mathrm{H}, \mathrm{t}-\mathrm{d}, J=2,7 \mathrm{~Hz}), 3.65(2 \mathrm{H}, \mathrm{s}), 3.74$ $(6 \mathrm{H}, \mathrm{s}), 3.90(1 \mathrm{H}, \mathrm{t}, J=7 \mathrm{~Hz})$.

4-Ethoxycarbonyl-3-oxo-2-pentyl-6-octenedioic acid 1ethyl, 8-methyl ester (32a). To a stirred suspension of $\mathrm{NaH}(4.8 \mathrm{~g}$ of $60 \%$ mineral oil dispersion) in dry THF $(250 \mathrm{ml})$ was added dropwise a solution of diethyl 3-oxo-2pentylglutarate $(31 \mathrm{a}, 21.8 \mathrm{~g})$ in dry THF $(50 \mathrm{ml})$ over 30 min at $0^{\circ} \mathrm{C}$ and the mixture stirred for $20 \mathrm{~min}$ at room temperature. To this was added dropwise a solution of methyl $\gamma$-bromocrotonate $(17.2 \mathrm{~g})$ in dry THF $(50 \mathrm{ml})$ over $30 \mathrm{~min}$ at $0^{\circ} \mathrm{C}$ under $\mathrm{N}_{2}$. After stirring for a further $20 \mathrm{hr}$ at room temperature, the reaction mixture was poured into $\mathrm{NH}_{4} \mathrm{Cl}$ aq. and extracted with ether. The extract was washed with brine, dried over $\mathrm{MgSO}_{4}$ and concentrated. The residue was distilled to give the recovered $31 \mathrm{a}(3.4 \mathrm{~g})$ and 32a $(20.1 \mathrm{~g}, 80 \%$ based on the recovery of 31a): bp $160 \sim 166^{\circ} \mathrm{C} / 1 \mathrm{mmHg}$. IR $v_{\max }^{\text {film }} \mathrm{cm}^{-1}: 1730,1660$. NMR $\left(\mathrm{CCl}_{4}\right) \delta: 0.88(3 \mathrm{H}, \mathrm{t}, J=7 \mathrm{~Hz}), 1.25(6 \mathrm{H}, \mathrm{t}, J=7 \mathrm{~Hz})$, $1.2 \sim 2.0(8 \mathrm{H}), 2.63(2 \mathrm{H}, \mathrm{t}, J=7 \mathrm{~Hz}), 3.52(1 \mathrm{H}, \mathrm{t}, J=7 \mathrm{~Hz})$, $3.60(3 \mathrm{H}, \mathrm{s}), 3.71(1 \mathrm{H}, \mathrm{t}, J=7 \mathrm{~Hz}), 4.10(4 \mathrm{H}, \mathrm{q}, J=7 \mathrm{~Hz})$, $5.73(1 \mathrm{H}, \mathrm{t}-\mathrm{d}, J=2,16 \mathrm{~Hz}), 6.68(1 \mathrm{H}, \mathrm{t}-\mathrm{d}, J=7,16 \mathrm{~Hz})$.

4-Ethoxycarbonyl-3-oxo-2-(2-pentynyl)-6-octenedioic acid 1-ethyl, 8-methyl ester. (32b). In the same manner, diethyl 3-oxo-2-(2-pentynyl) glutarate $(31 \mathrm{~b}, 26.8 \mathrm{~g})$ was treated with methyl $\gamma$-bromocrotonate $(21.6 \mathrm{~g})$ in the presence of $\mathrm{NaH}(6: 0 \mathrm{~g}$ of $60 \%$ mineral oil dispersion) at room temperature for $20 \mathrm{hr}$. After the same work-up, the residue on $\mathrm{SiO}_{2}$ chromatography $(1 \mathrm{~kg})$ eluted with $n$-hexaneEtOAc $(6: 1)$ gave the recovered $31 \mathrm{~b}(4.2 \mathrm{~g})$ and $32 \mathrm{~b}$
$(28.2 \mathrm{~g}, 91 \%$ based on the recovery of $31 \mathrm{~b}):$ IR $v_{\max }^{\mathrm{film}} \mathrm{cm}^{-1}$ : 1730, 1660. NMR $\left(\mathrm{CCl}_{4}\right) \delta: 1.08(3 \mathrm{H}, \mathrm{t}, J=7 \mathrm{~Hz}), 1.26$ $(6 \mathrm{H}, \mathrm{t}, J=7 \mathrm{~Hz}), 1.8 \sim 2.9(6 \mathrm{H}), 3.65(3 \mathrm{H}, \mathrm{s}), 3.73(1 \mathrm{H}, \mathrm{t}$, $J=7 \mathrm{~Hz}), 3.94(1 \mathrm{H}, \mathrm{t}, J=7 \mathrm{~Hz}), 4.16(4 \mathrm{H}, \mathrm{q}, J=7 \mathrm{~Hz}), 5.79$ $(1 \mathrm{H}, \mathrm{t}-\mathrm{d}, J=2,16 \mathrm{~Hz}), 6.72(1 \mathrm{H}, \mathrm{t}-\mathrm{d}, J=7,16 \mathrm{~Hz})$.

\section{2,5-Diethoxycarbonyl-3-methoxycarbonylmethyl-2-} pentylcyclopentanone (33a).

a) From 32a. A mixture of 32a (14.8 g) and $\mathrm{NaH}(1.6 \mathrm{~g}$ of $60 \%$ mineral oil dispersion) in dry benzene $(150 \mathrm{ml})$ was refluxed for $20 \mathrm{hr}$ under $\mathrm{N}_{2}$. The reaction mixture was cooled, washed with $\mathrm{NH}_{4} \mathrm{Cl}$ aq. and brine, dried over $\mathrm{MgSO}_{4}$ and concentrated. The residue was distilled to give 33a $(10.8 \mathrm{~g}, 73 \%)$ : bp $149 \sim 154^{\circ} \mathrm{C} / 1 \mathrm{mmHg}$. IR $v_{\max }^{\text {film }} \mathrm{cm}^{-1}$ : 1740. NMR $\left(\mathrm{CCl}_{4}\right) \delta: 0.88(3 \mathrm{H}, \mathrm{t}, J=7 \mathrm{~Hz}), 1.26(6 \mathrm{H}, \mathrm{t}$, $J=7 \mathrm{~Hz}), 1.1 \sim 2.7(13 \mathrm{H}), 3.60(3 \mathrm{H}, \mathrm{s}), 3.68(1 \mathrm{H}, \mathrm{t}, J=$ $7 \mathrm{~Hz}), 4.12(4 \mathrm{H}, \mathrm{q}, J=7 \mathrm{~Hz})$.

b) One-pot reaction from 31a. To a stirred suspension of $\mathrm{NaH}(2.0 \mathrm{~g}$ of $60 \%$ mineral oil dispersion) in dry benzene $(100 \mathrm{ml})$ was added dropwise a solution of 31a $(5.44 \mathrm{~g})$ in dry benzene $(20 \mathrm{ml})$ over $30 \mathrm{~min}$ at $0^{\circ} \mathrm{C}$ and the mixture was stirred for $30 \mathrm{~min}$ at room temperature. To this was added dropwise a solution of methyl $\gamma$-bromocrotonate $(5.37 \mathrm{~g})$ in dry benzene $(20 \mathrm{ml})$ over $30 \mathrm{~min}$ at $0^{\circ} \mathrm{C}$ under $\mathrm{N}_{2}$ and stirring was continued for $20 \mathrm{hr}$ at room temperature and then for $20 \mathrm{hr}$ at reflux. The reaction mixture was cooled, washed with $\mathrm{NH}_{4} \mathrm{Cl}$ aq. and brine, dried over $\mathrm{MgSO}_{4}$ and concentrated. The residue was distilled to give 33a $(4.58 \mathrm{~g}, 62 \%)$.

2,5-Diethoxycarbonyl-3-methoxycarbonylmethyl-2-(2pentynyl) cyclopentanone (33b).

a) From 32b. In the same manner as above, 32b (18.3 g) was treated with $\mathrm{NaH}(2.0 \mathrm{~g})$ in dry benzene $(200 \mathrm{ml})$ under reflux for $20 \mathrm{hr}$. After the same work-up, the residue on $\mathrm{SiO}_{2}$ chromatography $(500 \mathrm{~g})$ eluted with $n$-hexaneEtOAc $(6: 1)$ gave 33b $(12.4 \mathrm{~g}, 68 \%)$ : IR $v_{\max }^{\text {film }} \mathrm{cm}^{-1}: 1740$. $\operatorname{NMR}\left(\mathrm{CCl}_{4}\right) \delta: 1.07(3 \mathrm{H}, \mathrm{t}, J=7 \mathrm{~Hz}), 1.24$ and $1.28(6 \mathrm{H}, \mathrm{t}$, $J=7 \mathrm{~Hz}), 1.8 \sim 2.9(9 \mathrm{H}), 3.61$ and $3.68(3 \mathrm{H}, \mathrm{s}), 3.70(1 \mathrm{H}, \mathrm{t}$, $J=7 \mathrm{~Hz}), 4.07(3 \mathrm{H}, \mathrm{q}, J=7 \mathrm{~Hz})$.

b) One-pot reaction from $\mathbf{3 1 b}$. In the same manner as above, a suspension of $\mathbf{3 1 b}(5.36 \mathrm{~g})$ in dry benzene $(150 \mathrm{ml})$ containing $\mathrm{NaH}(2.0 \mathrm{~g})$ was treated with methyl $\gamma$-bromocrotonate $(5.37 \mathrm{~g})$ for $20 \mathrm{hr}$ at room temperature and then for $20 \mathrm{hr}$ at reflux. After the same work-up, the residue on $\mathrm{SiO}_{2}$ chromatography $(300 \mathrm{~g})$ eluted with $n$-hexaneEtOAc (6:1) gave 33b $(4.66 \mathrm{~g}, 63 \%)$.

Methyl dihydrojasmonate (5) from 33a. A mixture of 33a $(9.0 \mathrm{~g})$ and $6 \mathrm{~N} \mathrm{HCl}$ aq. $(30 \mathrm{ml})$ in $\mathrm{MeOH}(60 \mathrm{ml})$ was refluxed for $20 \mathrm{hr}$. The mixture was cooled, diluted with water and extracted with ether. The extract was washed with $\mathrm{NaHCO}_{3}$ aq. and brine, dried over $\mathrm{MgSO}_{4}$ and concentrated. The residue was distilled to give $5(3.6 \mathrm{~g}$, $66 \%$ ): bp $106 \sim 108^{\circ} \mathrm{C} / 1 \mathrm{mmHg}$.

Methyl dehydrojasmonate (29) from 33b. In the same 
manner, 33b $(9.0 \mathrm{~g})$ was treated with $6 \mathrm{~N} \mathrm{HCl}$ aq. $(30 \mathrm{ml})$ in $\mathrm{MeOH}(60 \mathrm{ml})$ under reflux for $20 \mathrm{hr}$. After the same workup, the residue was distilled to give $29(3.8 \mathrm{~g}, 70 \%)$ : bp $118 \sim 120^{\circ} \mathrm{C} / 1 \mathrm{mmHg}$.

Acknowledgments. The authors thank Dr. K. Kondo and Dr. D. Tunemoto, Sagami Chemical Research Center, for their generous gift of the spectral charts of methyl jasmonate. They are also much indebted to Dr. K. Hayashi and Dr. K. Kogami, T. Hasegawa Co. Ltd., for their encouragement to complete this work.

\section{REFERENCES}

1) a) E. Demole, D. Lederer and D. Mercier, Helv. Chim. Acta, 45, 675 (1962).

b) E. Demole, B. Willhalm and M. Stoll, Helv. Chim. Acta, 45, 1152 (1964).

2) H. Fukui, K. Koshimizu, Y. Yamazaki and S. Usuda, Agric. Biol. Chem., 41, 189 (1977).

3) a) E. Demole and M. Stoll, Helv. Chim. Acta, 45, 692 (1962).

b) K. Sisido, S. Kurozumi and K. Utimoto, J. Org. Chem., 34, 2661 (1969).

c) L. Givaudan et Cie, S. A. Genève, Brevet Ouest Allemand 2,008, 878 (1970); Chem. Abstr., 73, 109363d (1970).

d) G. Büchi and B. Egger, J. Org. Chem., 36, 2021 (1971).

e) A. I. Meyers and N. Nazarenko, J. Org. Chem., 38, 175 (1973).

f) P. Ducos and F. Rouessac, Tetrahedron, 29, 3233
(1973).

g) H. Tanaka and S. Torii, J. Org. Chem., 40, 462 (1975).

h) S. Torii, H. Tanaka and T. Mandai, J. Org. Chem., 40, 2221 (1975).

i) F. Johnson, D. G. Paul and D. Favara, German Patent 2,508, 295 (1975); Chem. Abstr., 84, 59783v (1976).

j) A. E. Greene and P. Crabbé, Tetrahedron Lett., 1976, 4867.

k) H. J. Monteiro, J. Org. Chem., 42, 2324 (1977).

1) S. Torii, H. Tanaka and Y. Kobayashi, J. Org. Chem., 42, 3473 (1977).

m) K. Kondo, Y. Takahata, K. Sugimoto and D. Tunemoto, Tetrahedron Lett., 1978, 907.

n) G. Stork, A. A. Ozorio and A. Y. W. Leong, Tetrahedron Lett., 1978, 5175.

o) F. Näf and R. Decorzant, Helv. Chim. Acta, 61, 2524 (1978).

4) H. B. Dykstra, J. Am. Chem. Soc., 57, 2235 (1935).

5) T. Kitahara, Y. Warita, K. Mori and M. Matsui, Abstract of Papers, the 1977 Annual Meeting of the Agricultural Chemical Society of Japan, 1977, p. 352.

6) S. N. Huckin and L. Weiler, J. Am. Chem. Soc., 96, 1082 (1974).

7) A. P. Krapcho and A. J. Lovery, Tetrahedron Lett., 1973, 957.

8) Y. Naoshima, S. Wakabayashi and H. Ueda, Agric. Biol. Chem., 43, 405 (1979), and references cited therein.

9) M. Iwamoto, Y. Takagi, T. Kitahara, K. Mori and M. Matsui, Agric. Biol. Chem., submitted for publication. 